\title{
Rousseau leitor de Seneca: entre os pressupostos e a originalidade de sua filosofia moral
}

\author{
Arlei de Espíndola \\ Tese de doutoramento, 2005 \\ Universidade Estadual de Campinas (UNICAMP) \\ Instituto de Filosofia e Ciências Humanas \\ Programa de Pós-Graduação em Filosofia
}

Essa tese se remete às fontes de leitura de Rousseau no pensamento antigo. Ela pretende mostrar, de um lado, que Rousseau beneficiou-se de sua leitura compenetrada, especialmente, dos livros de Sêneca. Assim, pode-se identificar pressupostos senequianos e estóicos em sua obra, sobretudo no âmbito de sua reflexão moral. De outro lado, o trabalho pretende afastar a suspeita de plágio que recai sobre o filósofo genebrino. Embora tenha extraído proveito de seu contato com os trabalhos do pensador estóico, Rousseau surge como um filósofo inovador no plano de sua reflexão moral.

Palavras-Chave: Iluminismo, Ética, Subjetividade. 